\title{
PENGARUH MODEL PEMBELAJARAN DAN KEMAMPUAN AWAL TERHADAP HASIL BELAJAR PESERTA DIDIK DALAM MATERI KIMIA KELAS XI IPA SMAN 4 MAKASSAR
}

\author{
Fandi Ahmad, Tabrani Gani ${ }^{1}$, Munir Tanre ${ }^{2}$ \\ ${ }^{1,2}$ Dosen Program Pascasarjana Universitas Negeri Makassar \\ Email:fandi_ahmad@gmail.com
}

\begin{abstract}
ABSTRAK
Penilitian ini bertujuan (i) Untuk mengetahui perbedaan hasil belajar peserta didik kelas XI IPA SMA Negeri 4 Makassar antara yang menggunakan model pembelajaran Think-PairShare (TPS) dan model pembelajaran langsung pada materi pokok Hidrolisis Garam (ii) Untuk mengetahui perbedaan hasil belajar peserta didik kelas XI IPA SMA Negeri 4 Makassar antara kemampuan awal tinggi dan kemampuan awal rendah pada materi pokok Hidrolisis Garam (iii) Untuk mengetahui interaksi antara model pembelajaran dengan kemampuan awal dalam mempengaruhi hasil belajar peserta didik kelas XI IPA SMA Negeri 4 Makassar pada materi pokok Hidrolisis Garam. Jenis penelitian adalah eksperimen semu dengan menggunakan desain faktorial $2 \times 2$. Populasi penelitian adalah seluruh peserta didik kelas XI IPA SMAN 4 Makassar tahun ajaran 2012/2013 yang berjumlah 7 kelas. Sampel penelitian sebanyak dua kelas yaitu kelas XI IPA1 dan kelas XI IPA3 yang dipilih secara random sampling. Pengujian hipotesis dilakukan dengan menggunakan analisis varian dua arah GLM Univariat dengan bantuan program SPSS 16.0. Hasil penelitian ini menunjukkan bahwa (1) Terdapat perbedaan hasil belajar peserta didik kelas XI IPA SMA Negeri 4 Makassar antara yang menggunakan model pembelajaran Think-Pair-Share (TPS) dan model pembelajaran langsung pada materi pokok Hidrolisis Garam. (2) Terdapat perbedaan hasil belajar peserta didik kelas XI IPA SMA Negeri 4 Makassar antara kemampuan awal tinggi dan kemampuan awal rendah pada materi pokok Hidrolisis Garam (3) Tidak terdapat interaksi antara model pembelajaran dengan kemampuan awal dalam mempengaruhi hasil belajar peserta didik dikelas XI IPA SMA Negeri 4 Makassar pada materi pokok Hidrolisis Garam. Rata-rata hasil belajar peserta didik yang diajar dengan model pembelajaran kooperatif ThinkPair-Share (TPS) lebih tinggi daripada yang diajar dengan menggunakan model pembelajaran langsung, serta hasil belajar peserta didik yang memiliki kemampuan awal yang tinggi lebih tinggi daripada peserta didik yang memiliki kemampuan awal yang rendah.
\end{abstract}

Kata kunci: Pembelajaran TPS, Pembelajaran Langsung, Kemampuan awal, Hasil Belajar.

\begin{abstract}
The study aimed at examining (1) the difference between learning outcomes of grade XI IPA students at SMAN 4 Makassar taught by using Think-Pair-Share (TPS) learning model and the ones using direct learning on Hydrolisis of Salt, (2) the diffrence between learning outcomes of grade XI IPA students at SMAN 4 Makassar with high initial ability on Hydrolysis of Salt, (3) the interaction betwen learning model and initial ability in influenching learning outcomes of grade XI IPA students at SMAN 4 Makassar on hydrolysis of Salt. The Study was a quasi-experiment research which employed factorial $2 \times 2$ design. The population of the study was all grade XI IPA students at SMAN 4 Makassar of academic year 2012/2013 with 7 classes. The samples were two classes, namely grade XI IPA1 and grade XI IPA3 selected using random sampling technique. Hypothesis test was conducted by employing twoway analysis of variant of GLM univariat supported by SPSS 16.0 program. The results of the study revealed that (1) therewas a difference between learning outcomes of grade XI IPA
\end{abstract}


students at SMAN 4 Makassar taught by using TPS learning model and the ones using direct learning on Hydrolysis of salt, (2) there was a difference between learning outcomes of grade XI IPA students at SMAN 4 Makassar with high initial ability and low initial ability on Hydrolysis of Salt, (3) there was interaction between learning model and initial ability in influenching learning outcomes of grade XI IPA students at SMAN 4 Makassar on Hydrolysis of Salt. The average of students' learning outcomes taught by using TPS learning model was higher than taught by using direct learning model, and learning outcomes of students who have high initial ability was higher than students with low initial ability.

Key words: Think-Pair-Share (TPS), Direct learning, Initial Ability, Learning Outcomes

\section{PENDAHULUAN}

Manusia mempunyai kelebihan dibandingkan makhluk ciptaan Tuhan yang lain, diantaranya adalah manusia dikaruniai akal. Kelebihan akal ini mendorong manusia untuk berpikir, sehingga manusia mempunyai derajat yang lebih tinggi daripada makhluk lainnya. Selain itu, manusia mampu mengembangkan pengetahuan dan pengalaman yang dimilikinya untuk dapat melakukan perbuatan yang selaras dengan lingkungan serta mampu mempertahankan kelangsungan hidupnya.

Pendidikan formal atau nonformal adalah sarana penting untuk mengembangkan kerangka berpikir manusia sehingga memperoleh kesuksesan. Hal ini disebabkan karena pendidikan berpengaruh dan berperan langsung terhadap perkembangan keseluruhan aspek kehidupan manusia. Pendidikan yang sekedar berorientasi pada materi akan menghasilkan peserta didik yang hanya berorientasi pada hasil akhir yang berupa angka, sementara segi pemahaman dan pengetahuan yang diperoleh dangkal, sehingga peserta didik hanya memiliki pemahaman yang bersifat verbal.

Faktor-faktor yang mempengaruhi pembelajaran diantaranya guru, peserta didik dan lingkungan. Dalam menunjang pembelajaran, guru tidak hanya sekedar menyampaikan materi saja tetapi juga berkewajiban untuk menciptakan suasana pembelajaran yang menyenangkan, kreatif, dinamis, dan logis. Keaktifan peserta didik tersebut dipengaruhi juga oleh kemampuan awal. Kemampuan awal itu perlu untuk mengomunikasikan pengetahuan selanjutnya (Nasution, 2008).

Fakta yang banyak ditemukan dalam proses belajar mengajar untuk memperoleh hasil yang sesuai dengan tujuan tidaklah mudah. Pada kegiatan belajar mengajar di sekolah sering dijumpai beberapa masalah, diantarannya adalah peserta didik yang mempunyai nilai rendah dalam sejumlah mata pelajaran, khususnya pada pelajaran kimia. Hal tersebut disebabkan karena sebagian besar objek kajian kimia bersifat abstrak. Oleh sebab itu, pembelajaran kimia hendaknya diawali dengan hal yang konkret ke abstrak, dari hal yang sederhana ke kompleks, dan dari yang mudah ke sulit. Penyajian materi kimia secara konkret dengan mengaitkannya dengan permasalahan nyata dalam kehidupan sehari-hari dapat memotivasi peserta didik untuk menemukan konsep yang sedang dipelajari sekaligus memberikan pemahaman kepada peserta didik tentang penerapan materi tersebut dalam kehidupan nyata. Maka dibutuhkanlah model pembelajaran yang membawa kehidupan nyata di dalamnya.

Salah satu masalah yang sering dihadapi guru dalam mengajarkan Kimia di SMA adalah kurangnya minat peserta didik terhadap materi pelajaran yang disampaikan. Hal ini dapat dilihat dari sikap peserta didik dalam menerima pelajaran, seperti kebiasaan peserta didik berbicara dengan temannya pada saat guru menerangkan di depan kelas, adanya peserta didik yang minta izin keluar pada saat pelajaran berlangsung. Salah satu 
penyebab kurangnya minat peserta didik terhadap materi pelajaran kimia yang diajarkan adalah model pembelajaran yang digunakan monoton, penyajian yang digunakan guru tidak menarik atau tidak sesuai dengan materi yang diajarkan.

Berdasarkan hasil observasi dan wawancara singkat dengan guru kimia SMAN 4 Makassar, hasil belajar peserta didik pada pelajaran kimia sangat rendah. Hal ini dikarenakan peserta didik masih banyak mengalami kesulitan dalam menyelesaikan soal-soal terutama yang berhubungan dengan hidrolisis garam. Kriteria ketuntasan perindividu yang digunakan di SMAN 4 Makassar yaitu $<75$ dikategorikan tidak tuntas, sedangkan nilai $\geq$ 75 dikategorikan tuntas. Dari kriteria ini pada tahun pelajaran 2011-2012 sebesar $50 \%$ dari keseluruhan peserta didik memperoleh nilai di bawah standar ketuntasan yang ditetapkan di SMAN 4 Makassar, sebelum mengikuti program remedial.

Kemampuan awal merupakan kemampuan yang dipandang sebagai masukan (input) yang harus dimiliki peserta didik sebelum mendapat kemampuan dan pengetahuan baru yang lebih tinggi. Seorang peserta didik akan lebih mudah memahami dan mempelajari materi pelajaran baru, apabila proses belajar mengajar didasarkan pada materi yang telah diketahui sebelumnya sehingga peserta didik tinggal mengembangkan kemampuan awal yang sudah dimilikinya menjadi kemampuan baru yang lebih tinggi. Adapun faktor-faktor yang mempengaruhi hasil belajar yaitu; (1) Faktor internal peserta didik meliputi karakteristik baik fisiologis maupun psikologis. Karakteristik fisiologis merupakan keadaan fisik peserta didik yang berpengaruh terhadap hasil belajar. Karakteristik psikologis antara lain kemampuan awal, latar belakang sosial, emosi, kemandirian belajar, disiplin belajar dan perbedaan kepribadian, (2) Faktor eksternal antara lain guru, tujuan, kurikulum, bahan pelajaran, metode, media, fasilitas, administrasi serta manajemen sekolah. Proses yang baik akan mendukung peserta didik untuk mendapatkan nilai yang baik. Permasalahan yang sering muncul dari peserta didik ialah peserta didik mempunyai keadaan awal yang berbeda-beda dan potensi yang berbeda-beda. Hal tersebut harus menjadi pertimbangan guru sebelum melaksanakan kegiatan belajar mengajar (Slameto, 2003).

Salah satu model pembelajaran yang dapat diterapkan untuk menarik minat peserta didik adalah dengan menggunakan model pembelajaran kooperatif tipe Think Pair Share (TPS). Model pembelajaran kooperatif tipe Think Pair Share (TPS) adalah merupakan jenis pembelajaran kooperatif yang dirancang untuk mempengaruhi pola interaksi siswa. Dan model pembelajaran ini memberikan waktu kepada para peserta didik untuk berpikir dan merespon serta saling bantu satu sama lain. Think Pair Share memberi peserta didik kesempatan untuk bekerja sendiri serta bekerja sama dengan orang lain sehingga peserta didik bertanggung jawab dalam perolehan nilai individu dan kelompok sehingga berdampak pada peningkatan minat dan motivasi peserta didik untuk mengikuti proses pembelajaran. (Trianto, 2009)

Selain model pembelajaran kooperatif tipe Think pair share, model pembelajaran yang biasa dilakukan oleh guru yaitu model pembelajaran langsung. Model pembelajaran langsung atau direct instruction dikenal dengan sebutan active teaching. Pembelajaran langsung juga dinamakan whole-class teaching. Penyebutan ini mengacu pada gaya mengajar di mana guru terlibat aktif dalam mengusung isi pelajaran kepada peserta didik dan mengajarkannya secara langsung kepada seluruh kelas. (Suprijono, 2009).

Ada beberapa penilitan yang relevan dengan judul penelitian ini diantaranya Sari, et al. (2012) yang dimuat dalam jurnal pendidikan Matematika, Volume 1, Nomor 4, Nopember 2012 Universitas Lampung yang meneliti pengaruh penggunaan pembelajaran kontekstual terhadap hasil belajar matematika siswa ditinjau dari 
kemampuan awal siswa pada SMPN 20 Bandar Lampung Semester Genap Tahun Pelajaran 2011/2012. Diperoleh bahwa penggunaan pembelajaran kontekstual tidak berpengaruh terhadap hasil belajar matematika siswa ditinjau dari kemampuan awal siswa. Selain itu Gultom, et al (2009) yang dimuat dalam jurnal pendidikan Matematika \& Sains , Vol 4(2), 2009 h 7781 Universitas Negeri Medan, yang meneliti pengaruh kemampuan awal dan model pembelajaran terhadap hasil belajar kimia siswa pada kelas IPA SMAN 5 Medan Semester Genap Tahun Pelajaran 2009/2010. Diperoleh bahwa tidak ada pengaruh kemampuan awal maupun model pembelajaran terhadap hasil belajar kimia, tetapi ada interaksi antara kemampuan awal dan model pembelajaran tersebut.

Berdasarkan berbagai permasalahan di atas, maka yang menjadi telaah utama dalam penelitian ini adalah Pengaruh Model Pembelajaran dan Kemampuan Awal terhadap Hasil Belajar Peserta didik Dalam Materi Kimia Kelas XI SMAN 4 Makassar.

\section{METODE PENELITIAN}

Jenis penelitian yang digunakan adalah eksperimen semu (quasi experiment). Pemilihan jenis ini didasarkan pada sasaran penelitian yakni manusia (peserta didik) dalam bidang pendidikan, dimana akan sangat sulit jika harus mengontrol semua variabel yang ada, layaknya pada eksperimen murni. Oleh karena itu, peneliti memilih jenis penelitian quasi experiment.

Desain penelitian yang digunakan dalam penelitian ini adalah desain faktorial $2 \times 2$. Pengambilan datanya dengan menggunakan treatment posttest. Desain analisis faktorial 2 x 2 dalam penelitian ini, disajikan dalam tabel sebagai berikut sebagai berikut :

Tabel 3.1 Desain Faktorial 2 x 2

\begin{tabular}{|l|c|c|}
$\begin{array}{l}\text { Kemampuan } \\
\text { Mwal } \\
\text { Medel }\end{array}$ & $\begin{array}{c}\text { Tinggi } \\
\left(\mathrm{B}_{1}\right)\end{array}$ & $\begin{array}{c}\text { Rendah } \\
\left(\mathrm{B}_{2}\right)\end{array}$ \\
\hline $\operatorname{TPS}\left(\mathrm{A}_{1}\right)$ & $\mathrm{A}_{1} \mathrm{~B}_{1}$ & $\mathrm{~A}_{1} \mathrm{~B}_{2}$ \\
\hline Langsung $\left(\mathrm{A}_{2}\right)$ & $\mathrm{A}_{2} \mathrm{~B}_{1}$ & $\mathrm{~A}_{2} \mathrm{~B}_{2}$ \\
\hline
\end{tabular}

Variabel Penelitian penelitian ini terdiri dari 2 macam variabel, yaitu variabel bebas (independent) dan variabel terikat (dependent)

1. Variabel bebas dalam penelitian ini antara lain:

a. Variabel bebas manipulatif yaitu model pembelajaran kooperatif tipe Think-Pair-Share (TPS) dan model pembelajaran langsung.

b. Variabel bebas atributif yaitu kemampuan awal, dengan variasi kemampuan awal tinggi dan kemampuan awal rendah.

2. Variabel terikat dalam penelitian ini adalah hasil belajar kimia peserta didik.

Populasi dalam penelitian ini adalah seluruh kelas XI SMA Negeri 4 Makassar tahun pelajaran 2012/2013 yang terdiri dari enam kelas. Jumlah peserta didik setiap kelas terdiri dari 35 orang. Karena semua kelas XI diasumsikan memiliki kemampuan yang sama, maka dilakukan pengambilan sampel secara random sampling. Penentuan kelompok yang menggunkan model pembelajaran TPS dan pembelajaran langsung dilakukan dengan cara pengundian, dan diperoleh kelas XI IPA1 sebagai kelas yang menggunakan model pembelajaran kooperatif tipe TPS dan XI IPA3 sebagi kelas yang menggunakan model pembelajaran langsung.

Dalam pelaksanaan eksperimen ini, peneliti akan melakukan penelitian dalam dua tahapan yaitu sebagai berikut:

Pada tahap perencanaan kegiatan yang dilaksanakan adalah sebagai berikut:

Mengadakan observasi ke sekolah dan berkonsultasi dengan guru bidang studi kimia kelas XI mengenai kelas yang akan digunakan, waktu penelitian, keadaan peserta didik serta materi pelajaran yang akan diteliti, menyusun program pengajaran dalam bentuk rencana pengajaran, Menyusun soal-soal tugas dan lembar kegiatan peserta didik yang disesuaikan dengan materi pelajaran, menyusun tes hasil belajar belajar, dan menentukan batas kelompok peserta didik kemampuan awal tinggi dan rendah, nilai kemampuan awal 
diperoleh dari nilai ulangan harian materi sebelum hidrolisis garam yaitu larutan penyangga. Adapun rumus yang digunakan untuk mengelompokkan kemampuan awal siswa sebagai berikut:

Skor $\geq \mathrm{x}^{-}+1 / 2$ SD $=$ Kategori Tinggi Skor $<x^{-}+1 / 2$ SD $=$ Kategori Rendah

Dari hasil pengelompokkan kemampuan awal diperoleh pada kelas yang menggunakan model pembelajaran TPS, untuk kategori kemampuan awal tinggi sebanyak 15 orang dan kemampuan awal rendah 19 orang, sedangkan untuk kelas yang menggunakan model pembelajaran langsung, untuk kategori kemampuan awal tinggi sebanyak 14 orang dan kemampuan awal rendah sebanyak 20 orang.

Kegiatan pembelajaran dalam penelitian ini di rencanakan berlangsung selama 5 kali pertemuan dengan setiap kali pertemuan terdiri atas 2 jam pelajaran. Satu jam pelajaran selama 45 menit (4 kali pertemuan untuk penerimaan materi, 1 kali pertemuan untuk posttest).

Untuk mengetahui hasil belajar peserta didik, dalam penelitian ini digunakan tes hasil belajar peserta didik berupa soal essay yang diberikan kepada peserta didik yang berisikan pertanyaan-pertanyaan yang berhubungan dengan hidrolisis garam. Jumlah soal sebelum divalidasi sebanyak 8 butir soal, dan di uji validitas dan reliabilitasnya dengan menggunakan validitas isi.

Data hasil validasi ahli dianalisis dengan mempertimbangkan penilaian, masukan, komentar, dan saran-saran validator. Hasil analisis tersebut dijadikan sebagai pedoman untuk merevisi produk yang masih mendapat penilaian kurang. Relevansi kedua pakar secara menyeluruh merupakan validitas isi Gregory yaitu berupa koefisien validitas isi. Koefisien validitas isi dihitung berdasar rumus sebagai berikut (Ruslan, 2009).

Berdasarkan perhitungan, maka hasil analisis kevalidan yang dilakukan oleh 2 orang validator menunjukkan bahwa rata- rata penilaian terhadap semua komponen lebih besar dari $75 \%$ yang menunjukkan bahwa setiap komponen pada perangkat pembelajaran dan tes hasil belajar berada pada kategori valid (V). Sehingga komponen secara keseluruhan dapat digunakan atau diterapkan dalam penlitian ini.

Teknik pengumpulan data menggunakan teknik dokumentasi dan tes hasil belajar. Teknik dokumentasi untuk memperoleh data kemampuan awal peserta didik yang ditunjukan dengan nilai hasil belajar pada materi sebelumnya yaitu larutan penyangga. Sedangkan teknik tes digunakan untuk memperoleh data hasil belajar kimia peserta didik yang diperoleh dari tes yang diberikan pada akhir tahapan pembelajaran dengan menggunakan soal essay Tes yang diberikan berupa tes hasil belajar kimia peserta didik. Sebelum dilakukan pengambilan data, perangkat tes harus memenuhi validitas isi.

Pengujian hipotesis dilakukan dengan menggunakan ANAVA dua jalur. Sebelum melakukan perhitungan dengan ANAVA dilakukan uji prasyarat yaitu uji normalitas dan uji homogenitas variansi.

\section{HASIL PENELITIAN}

Hasil analisis deskriptif untuk hasil belajar peserta didik pada kelas yang diajar dengan menggunakan model pembelajaran kooperatif tipe TPS dan model pembelajaran langsung dapat dilihat pada Tabel 1.

Tabel 1. Statistik Deskriptif Nilai Hasil Belajar

\begin{tabular}{|c|c|c|c|c|}
\hline \multirow{2}{*}{ Statistik } & \multicolumn{3}{|c|}{ Model Pemb. TPS } & \multicolumn{2}{|c|}{$\begin{array}{c}\text { Model Pemb. } \\
\text { Langsung }\end{array}$} \\
\cline { 2 - 5 } & \multicolumn{3}{|c|}{ Kemampuan Awal } \\
\cline { 2 - 5 } Singgi & Rendah & Tinggi & Rendah \\
\hline Subjek & 15 & 19 & 14 & 20 \\
\hline Mean & 86,87 & 76,63 & 78,71 & 72,90 \\
\hline Median & 86,00 & 74,00 & 76,50 & 73,00 \\
\hline Modus & 90,00 & 60,00 & 70,00 & 73,00 \\
\hline
\end{tabular}




\begin{tabular}{|c|c|c|c|c|}
\hline $\begin{array}{c}\text { Standar } \\
\text { deviasi }\end{array}$ & 7,42 & 11,55 & 7,15 & 3,93 \\
\hline $\begin{array}{c}\text { Varian } \\
\text { si }\end{array}$ & 55,12 & 133,47 & 51,14 & 15,46 \\
\hline $\begin{array}{c}\text { Minim } \\
\text { um }\end{array}$ & 75,00 & 60,00 & 70,00 & 65,00 \\
\hline $\begin{array}{c}\text { Maxim } \\
\text { um }\end{array}$ & 98,00 & 98,00 & 91,00 & 79,00 \\
\hline
\end{tabular}

Berdasarkan Tabel 1 di atas, dapat dilihat bahwa antara pembelajaran TPS dan pembelajaran langsung terdapat perbedaan nilai rata-rata hasil belajar siswa. Pada pembelajaran kontekstual, nilai rata-rata hasil belajar siswa dari masingmasing kategori kemampuan awal siswa secara keseluruhan maupun masing-masing kategori lebih tinggi dari pada pembelajaran langsung.

Namun perbedaan tersebut belum diketahui memiliki keberartian atau tidak. Maka akan dianalisis lanjut untuk menentukan hipotesis penelitian ini. Pengujian hipotesis menggunakan analisis variansi (ANAVA) dengan uji prasyarat telah terpenuhi yaitu populasi berdistribusi normal dan homogen, Berikut hasil perhitungan uji normalitas, terangkum pada tabel di bawah ini.

Tabel 2 Rangkuman Hasil Uji Coba Normalitas Data Hasil Belajar Kimia

\begin{tabular}{|c|l|c|l|}
\hline Kelas & Kelompok & P & Kesimpulan \\
\hline \multirow{2}{*}{ TPS } & Tinggi & $.200^{*}$ & Ho diterima \\
\cline { 2 - 4 } & Rendah & $.200^{*}$ & Ho diterima \\
\hline \multirow{2}{*}{ P.Langsung } & Tinggi & $.200^{*}$ & Ho diterima \\
\cline { 2 - 4 } & Rendah & $.200^{*}$ & Ho diterima \\
\hline
\end{tabular}

Berdasarkan tabel di atas disimpulkan bahwa data pada setiap kelompok berasal dari populasi yang berdistribusi normal. Sedangkan uji homogenitas variansi terangkum padaTabel 3 berikut.
Tabel 3. Rangkuman Hasil Uji Coba Normalitas Data Hasil Belajar Kimia

\begin{tabular}{|c|l|r|r|r|c|}
\hline \multicolumn{2}{|c|}{$\begin{array}{c}\text { Hasil } \\
\text { Belajar }\end{array}$} & $\begin{array}{l}\text { Levene } \\
\text { Statistic }\end{array}$ & df1 & \multicolumn{1}{c|}{ df2 } & P \\
& Mean & 3.129 & 1 & 32 & .086 \\
\cline { 2 - 6 } & $\begin{array}{l}\text { Based on } \\
\text { Median }\end{array}$ & 2.046 & 1 & 32 & .162 \\
\cline { 2 - 6 } & $\begin{array}{l}\text { Based on } \\
\text { Median } \\
\text { and with } \\
\text { adjusted } \\
\text { df }\end{array}$ & 2.046 & 1 & 23.206 & .165 \\
\cline { 2 - 6 } & $\begin{array}{l}\text { Based on } \\
\text { trimmed } \\
\text { mean }\end{array}$ & 2.990 & 1 & 32 & .093 \\
\hline
\end{tabular}

Berdasarkan tabel di atas, dapat disimpulkan bahwa varians kedua populasi sama untuk setiap pasangan kelompok data atau dengan kata lain data pada setiap pasangan kelompok homogen. Setelah kedua populasi berdistribusi normal dan homogen, maka dilanjutkan dengan penghitungan uji hipotesis. Pada pengujian hipotesis ANAVA dua jalur dan terangkum pada Tabel 4 berikut.

\begin{tabular}{|c|c|c|c|c|c|}
\hline Source & $\begin{array}{l}\text { Type I Sum } \\
\text { of Squares }\end{array}$ & Df & $\begin{array}{l}\text { Mean } \\
\text { Square }\end{array}$ & $\mathrm{F}$ & $\mathrm{P}$ \\
\hline $\begin{array}{l}\text { Corrected } \\
\text { Model }\end{array}$ & $417779.397 \mathrm{a}$ & 4 & $\begin{array}{r}104444.8 \\
49\end{array}$ & $1.612 \mathrm{E} 3$ & .000 \\
\hline $\begin{array}{l}\text { Model } \\
\text { Pembelajaran }\end{array}$ & 416637.676 & 2 & $\begin{array}{r}208318.8 \\
38\end{array}$ & $3.214 \mathrm{E} 3$ & .000 \\
\hline $\begin{array}{l}\text { Kemampuan } \\
\text { Awal }\end{array}$ & 1125.804 & 1 & 1125.804 & 11.104 & .001 \\
\hline $\begin{array}{l}\text { Model } \\
\text { Pembelajaran* } \\
\text { Kemp.Awal }\end{array}$ & 15.917 & 1 & 15.917 & 44.576 & .622 \\
\hline Error & 4147.603 & 64 & 64.806 & & \\
\hline Total & 421927.000 & 68 & & & \\
\hline
\end{tabular}

Hasil análisis statistik infrensial untuk hipotesis pertama diperoleh nilai $\mathrm{p}<\alpha=$ 0,05, berarti Ho ditolak dan $\mathrm{H} 1$ diterima. Sehingga disimpulkan bahwa, terdapat perbedaan hasil belajar peserta didik kelas XI IPA SMA Negeri 4 Makassar antara 
yang menggunakan model pembelajaran Think-Pair-Share (TPS) dan model pembelajaran langsung pada materi pokok Hidrolisis Garam.

Adapun yang menyebabkan hal ini, dikarenakan pada model pembelajaran kooperatif tipe TPS, peserta didik banyak diberi kesempatan untuk bekerja sendiri serta bekerjasama dengan rekan kerja dalam kegiatan pembelajaran. Model pembelajaran ini memberikan kesempatan kepada peserta didik untuk berpikir, kemudian berpasangan untuk saling membagi pengetahuan, peserta didik merasa senang karena dihargai dan dilayani dengan baik bagaimana belajar berdiskusi dan menerima pendapat.

Diskusi dalam kelompok kecil dan diskusi antar kelompok pada pembelajaran dengan model kooperatif tipe TPS menurut teori mampu mempertajam pemikiran untuk memahami konsep yang sulit dan memperdalam pemahaman peserta didik untuk menyelesaikan masalah yang dapat menumbuhkan hasil belajar peserta didik.

Pada Hipotesis kedua hasil analisis statistik infrensial yang diperoleh nilai $\mathrm{p}<\alpha$ $=0,05$, berarti Ho ditolak dan H1 diterima. Dengan demikian terdapat perbedaan hasil belajar peserta didik yang mempunyai kemampuan awal yang tinggi dengan kemampuan awal yang rendah.

Peserta didik yang memiliki kemampuan awal tinggi berarti peserta didik sudah siap dalam menerima pelajaran yang baru. Karena dengan kemampuan awal kimia kategori tinggi peserta didik akan mampu memahami bahan atau materi pelajaran baru atau memecahkan masalah yang berkaitan dengan materi pelajaran. Selain itu, kemampuan awal tersebut dapat digunakan sebagai dasar untuk menerima pengalaman dan pengertian baru.

Berdasarkan penelitian di SMAN 4 Makassar, diperoleh beberapa perbedaan yakni bagi peserta didik yang mempunyai kemampuan awal tinggi dapat mengerjakan LKS dengan cepat, sehingga akan membantu peserta didik yang mempunyai kemampuan awal rendah. Aktivitas ini mengindikasikan bahwa peserta didik tersebut memahami konsep dan mampu mentransfer pengetahuannya kepada temannya. Peserta didik yang mempunyai kemampuan awal rendah, menyelasaikan soal-soal dengan alokasi waktu yang telah ditentukan bahkan membutuhkan waktu yang lebih banyak, namun masih membutuhkan sharing dengan temannya dan memerlukan bimbingan yang lebih intensif baik dari guru maupun dari teman.

Pada hipotesis ketiga hasil analisisis statistik infrensial diperoleh nilai signifikasi adalah 0,266. Nilai tersebut lebih besar dibandingkan nilai signifikansi yang telah ditetapkan yaitu $\alpha=0,05$, berarti Ho diterima dan H1 ditolak. Dengan demikian tidak terdapat interaksi antara model pembelajaran Think-Pair-Share (TPS) dan model pembelajaran langsung dengan kemampuan awal dalam mempengaruhi hasil belajar Peserta didik. Artinya tidak ada interaksi antara model pembelajaran dengan kemampuan awal peserta didik dalam mempengaruhi hasil belajar Peserta didik . Hipotesis ada interaksi antara model pembelajaran dengan kemampuan awal dapat pula dijelaskan secara grafik sebagaimana disajikan pada Gambar 1.

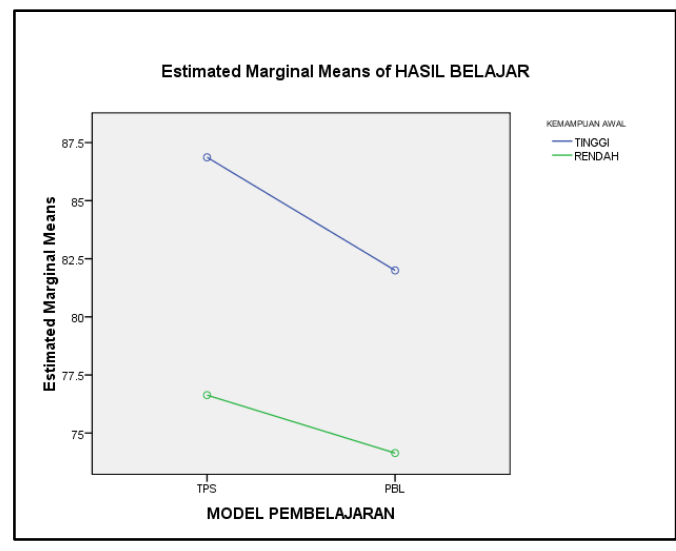

Interaksi terjadi jika terdapat perpotongan garis koperatif tipe TPS dan model pembelajaran langsung. Pada Gambar 4.1 terlihat tidak adanya garis perpotongan sehingga dapat disimpulkan bahwa tidak terdapat interaksi antara model pembelajaran dan kemampuan awal dalam mempengaruhi hasil belajar peserta didik.

Dengan demikian dapat diketahui bahwa hasil belajar peserta didik yang 
diajar dengan menggunakan model pembelajaran kooperatif tipe TPS lebih baik daripada dengan model pembelajaran langsung, baik pada peserta didik yang mempunyai kemampuan awal tinggi maupun rendah. Namun tak ada interaksi antara pengaruh model pembelajaran dan kemampuan awal yang dimiliki peserta didik.kelas XI IPA SMA Negeri 4 Makassar pada materi pokok Hidrolisis Garam.

Berdasarkan hasil penelitan menunjukkan bahwa baik peserta didik yang memiliki kemampuan awal tinggi dan kemampuan awal rendah yang diajar dengan menggunakan model pembelajaran TPS dan pembelajaran langsung, terjadi peningkatan hasil belajar tetapi untuk peserta didik yang memiliki kemampuan awal rendah hasil belajar yang diperoleh masih dibawah hasil belajar peserta didik yang memiliki kemampuan awal tinggi. Hal ini dikarenakan seorang peserta didik akan lebih mudah memahami dan mempelajari materi pelajaran baru, apabila proses belajar mengajar didasarkan pada materi yang telah diketahui sebelumnya sehingga peserta didik tinggal mengembangkan kemampuan awal yang sudah dimilikinya menjadi kemampuan baru yang lebih tinggi. Pada penelitian ini juga terlihat antara model pembelajaran dengan kemampuan awal peserta didik tidak saling mempengaruhi. Dengan demikian tidak ada kontribusi secara bersama-sama yang disumbangkan antara model dengan pemahaman konsep awal untuk meningkatkan hasil belajar peserta didik. Peserta didik yang memiliki pemahaman konsep awal yang tinggi tanpa model pembelajaran akan memperoleh hasil belajar yang tinggi. Peserta didik yang mempunyai pemahaman konsep awal yang rendah maka akan memperoleh hasil belajar yang rendah.

\section{KESIMPULAN}

Berdasarkan hasil penelitian dan pembahasan maka dapat disimpulkan bahwa:

1. Ada pengaruh model pembelajaran terhadap hasil belajar kimia peserta didik dikelas XI IPA SMA Negeri 4 Makassar pada materi pokok Hidrolisis Garam.

2. Ada pengaruh kemampuan awal terhadap hasil belajar kimia peserta didik dikelas XI IPA SMA Negeri 4 Makassar pada materi pokok Hidrolisis Garam.

3. Tidak terdapat interaksi antara model pembelajaran dengan kemampuan awal dalam mempengaruhi hasil belajar peserta didik dikelas XI IPA SMA Negeri 4 Makassar pada materi pokok Hidrolisis Garam.

\section{DAFTAR PUSTAKA}

Gultom., Silitonga., 2009. Pengaruh Kemampuan Awal dan Model Pembelajaran Terhadap Hasil Belajar Kimia Siswa SMA. Jurnal Pend. Mat \& Sains Vol 4(2) 2009 h77-81 UNIMED. (Diakses pada tanggal 31 Januari 2013).

Nasution, S. 2008. Berbagai Pendekatan dalam Proses Belajar \& Mengajar. Jakarta: Bumi Aksara.

Ruslan. 2009. Validitas Isi. Buletin Pa'biritta No. 10 Tahun VI September.

Sari., Sutiarso., \& Asnawati. 2012. Pengaruh Penggunaan

Pembelajaran Kontekstual Terhadap Hasil Belajar Matematika Siswa Ditinjau Dari Kemampuan Awal Siswa. jurnal pendidikan Matematika, Volume 1, Nomor 4, Nopember $2012 \quad$ Universitas Lampung.

Slameto. 2003. Belajar dan FaktorFaktor Yang Mempengaruhinya. Jakarta: Rineka Cipta.

Suharsimi. 2009. Dasar-Dasar Evaluasi Pendidikan Edisi Revisi. Jakarta: Bumi Aksara

Suprijono, Agus. 2010. Cooperative Learning Teori \& Aplikasi Paikem. Surabaya: Pustaka Belajar.

Trianto. 2009a. Model-Model Pembelajaran Pembelajaran Inovatif Berorientasi Konstruktivistik. Jakarta: Prestasi Pustaka. 